\title{
Dealing With Non-Performing Loans During The Bank Restructuring Process in Vietnam: Assessment Using The AHP and TOPSIS Methods
}

\author{
Tran Thi Van Anhac, Nguyen Thi Nhung ${ }^{*} a c$, Tran Thi Thanh Tuc \\ ${ }^{\mathrm{a}}$ University of Economics and Business, Vietnam \\ ${ }^{\mathrm{b}}$ Vietnam Japan University, Vietnam \\ 'Vietnam National University, Vietnam
}

\begin{abstract}
This article aims to assess the solutions that have been implemented in Vietnam to deal with non-performing loan(s) (NPLs) in the banking system. By trying to build evaluation criteria through a literature review and an expert survey, as well as using the analytic hierarchy process (AHP) and technique for order preference by similarity to ideal solution (TOPSIS), this research measures the effectiveness of the resolution of NPLs in Vietnam through many factors. The empirical results show that, in the past, the banking system in Vietnam has not dealt very well with bad debt, as it mostly uses traditional methods such as NPL write-offs by loan loss reserves or the liquidation of collateral. Based on our consideration of the NPLs' resolutions that the Vietnamese banking system has implemented recently, we propose some suggestions to improve the necessary conditions for applying more market-based solutions, such as debt-equity swaps and securitization to thoroughly resolve the NPLs in Vietnam.
\end{abstract}

Keywords: analytic hierarchy process (AHP), fuzzy technique for order preference by similarity to ideal solution (fuzzy TOPSIS), non-performing loan(s) (NPLs), Vietnam.

JEL Classification: J10, G21, G20 


\section{Introduction}

Over the last 15 years, the process of restructuring Vietnam's commercial banking system has been divided into three phases. The first period was from 1998 to 2003, after the Asian financial crisis of 1997-1998. The second phase, from 2005 to 2008, was the period when Vietnam joined the World Trade Organization (WTO). The third stage from 2011 to 2015 was the period of economic restructuring under Project No. 254 issued by the Government of Vietnam. The purpose of this project was to focus on stabilizing the banking system, and enhancing the capability of financial institutions to handle various serious problems such as non-performing loan(s) (NPLs) in the banking system in Vietnam.

However, eight years after the implementation of Project No. 254, the NPLs still remain a critical issue for the Vietnamese banking system. The State Bank of Vietnam (ie the Central Bank of Vietnam) began to officially publish data on the NPLs in the Vietnamese banking system in 2012. According to data published on the website of the State Bank of Vietnam, the NPL ratio of the banking system in the period 2012 to 2016 tended to decrease gradually over the years. Specifically, the NPL ratio was at $4.08 \%$ in 2012 and decreased to $3.79 \%$ in 2013 . In the following years, 2014, 2014, and 2016, the NPL ratio continued to decline to $3.25 \%$, $2.6 \%$ and $2.55 \%$, respectively. The Financial Market Overview Report for 2018, published by the National Financial Supervisory Commission (NFSC) in late 2018, showed that the NPL ratio of the banking system in Vietnam at the end of 2018 was $2.4 \%$, only slightly lower than the 2017 rate of $2.5 \%$. According to the NFSC, the value of NPLs processed by the Vietnamese banking system in 2018 increased by about 30\% compared to 2017, in which the handling of bad debts using loan loss reserves accounted for $59.8 \%$, debt collection from customers accounted for $33.2 \%$, the liquidation of collateral accounted for $3 \%$, while the remaining bad debts were handled using other methods.

The above-mentioned data shows that the Vietnamese banking system dealt with bad debts mainly through the increase in loan loss provisions. The NFSC report (2018) said that the loan loss provisions of Vietnamese banks increased by $30.1 \%$ compared to the end of 2017. In fact the Vietnamese banks have not yet found suitable methods to effectively deal with NPLs. Therefore, it is urgent to re-evaluate the solutions for NPLs that have been applied recently, to draw the necessary recommendations to implement some more market-based approaches like securitization to thoroughly resolve the NPLs in the Vietnamese banking system.

The main objective of this research is to evaluate the solutions that have recently been applied by the Vietnamese banks in order to deal with their NPLs. To achieve this goal, the authors first developed evaluation criteria through the use of the AHP and TOPSIS methods. Next, the authors used the criteria to evaluate the effectiveness of the NPL solutions, in order to prioritize these solutions. Finally, the authors made some recommendations to improve the conditions for the successful implementation of the NPL resolutions for the banking system in Vietnam. The research questions for this article are: What solutions has Vietnam recently applied to deal with the bad debts of the banking system? What will Vietnam need to do to implement market-based solutions to handle NPLs in the coming period? 
To the best of our knowledge, this is the first paper that tries to build evaluation criteria for solutions dealing with NPLs, as well assessing the resolution of NPLs in Vietnam through evaluating each criterion by using AHP and TOPSIS. The findings of this research will contribute to the literature on various methods for handling NPLs in a banking system. In addition, this article provides empirical evidence about the effectiveness of each factor in each solution, and how each solution dealt with NPLs during the bank restructuring process in Vietnam.

This paper consists of six parts. The first part is the introduction. The second part reviews the literature about NPLs and solutions for dealing with NPLs in banking systems. The methodology and data used to evaluate the resolution of the NPLs are presented in the $3^{\text {rd }}$ part. The results are shown in part 4. The discussion is given in part 5 . Some conclusions as well as some limitations of the research are found in the last part.

\section{Literature Review}

\section{Non-performing loan(s) (NPLs) in a banking system: definition, classifica- tion and risks}

It is common practice for governments to issue regulations regarding the definition and classification of NPLs (ECB, 2016; ECB, 2017; SBV, 2005; Government of Nova Scotia, 2005). For example, according to the definition of the European Central Bank, non-performing loans are: "loans other than those held for trading that satisfy either or both of the following criteria: (a) material loans which are more than 90 days past-due; (b) the debtor is assessed as unlikely to pay its credit obligations in full without the realiza- tion of collateral, regardless of the existence of any past-due amount or of the number of days past due. Non-performing loans include defaulted and impaired loans" (ECB, 2017). In Vietnam, bad debt is not directly defined, but indirectly determined through regulations on debt classification to deal with credit risks in credit institutions' operations. Specifically, according to articles 6 and 7 of Decision No. 493/2005 / QD-NHNN issued by the State Bank of Vietnam in 2005, bad debts are substandard debts, doubtful debts and potentially unrecoverable debts (SBV, 2005).

To classify NPLs, the banks need to consider implementing specific tasks such as (i) incorporating NPLs according to groups with the same credit risk characteristics, (ii) calculating the level of past losses of respective groups to accurately identify risk parameters and (iii) providing ways to estimate the extent of future losses for those groups. Based on these factors, the banks will decide when an individual allowance (i.e. for an individual financial asset/debtor) or an allowance determined collectively (i.e. for a group of financial assets with similar credit risk characteristics) should be given. A loan classified as an NPL is an impairment trigger that should be tested for impairment, either individually or collectively (ECB, 2016). The criteria used by many governments to classify a loan as non-performing include days past due status, significant financial difficulty of the borrower, breach of contract, forbearance, borrower bankruptcy or other financial reorganization (D'Hulster et al., 2014, Barisitz, 2011; Barisitz, 2012; Barisitz, 2013).

The increase in the ratio of NPLs means a decline in the quality of the loan portfolio and a direct cause of serious problems in the banking system, which may increase the risk of banks 'bankruptcy as well as a finan- 
Gadjah Mada International Journal of Business - September-December, Vol. 22, No. 3, 2020

cial crisis in both developed and developing countries (Saoussen et al, 2017). The increase of bad debts may lead to the fluctuation of macroeconomic indicators reflecting the health of the economy, including short-term interest rate increases, real interest rate reductions, increasing unemployment rates and inflation indexes and increases in the trade deficit. It can be said that bad debt can increase the system risk for many countries (Saoussen et al, 2017).

\section{Different methods dealing with NPLs and the necessary conditions for their implementation in a banking system}

In the face of frequent and abnormal fluctuations that negatively affect the overall economy as a whole, and the financial system in particular in some countries, the treatment of NPLs by banking systems has recently become a matter of concern to many governments. Therefore, the methods used to resolve NPLs, as implemented by various countries, are also the subject of many studies around the world. Through theoretical and empirical research, it can be clearly seen that there are four main methods for resolving NPLs including: (i) debt-equity swaps, (ii) securitization, (iii) liquidation of collateral and (iv) NPL write-offs by loan loss reserves. Securitization is considered to be an off-balance sheet strategy while debt-equitiy swaps, the liquidation of collateral, and NPL writeoffs by loan loss reserves are categorized as on-balance sheet strategies.

\section{Debt-Equity Swap}

Debt restructuring is a process that allows a private or public company, or a sovereign entity in financial distress and having problems with its cash flow, to reduce or re- negotiate its delinquent debts to improve or restore liquidity to continue working normally. The debt-equity swap, as an instrument for dealing with NPLs, was used by many heavily indebted poor countries (HIPC) during the period of the international debt crisis in the 1980s (Moye, 2001). It was advocated as a potential solution for the subprime mortgage crisis of 2007 and 2008 by economists such as Sachs (2009) or Stiglitz (2009), who wrote that reducing bank debt levels by converting debt into equity would increase confidence in the financial system (Stiglitz, 2009). Debt-equity swaps were also one of the methods used by the South Korean authorities to handle NPLs, which were the result of too much spending and debt (Park et al, 2006). The quick response of the Government of South Korea to reconstruct NPLs proved to be particularly useful in mitigating the financial crisis and maintaining economic growth (Spilimbergo et al, 2008; Iwulska, 2012). Recently, this technique has been used by the Government of China to support its financial institutions in tackling their mounting NPLs (Fitch, 2016; Molet and Wong, 2017), which have increased to a record level of $237 \%$ of GDP (Wildau and Weinland, 2016; Zhang and Miller, 2016). Debt-to-equity swaps are considered by the Government of China to be an effective measure that could save banks from NPLs (Bulloch, 2016) and could potentially prevent a future debt crisis (Xinhuanet, 2016).

A traditional debt swap involves the voluntary exchange by a creditor with its debtors, of debt for cash, other assets or a new obligation with different repayment terms (Moye, 2001). Usually debtors sell various assets including physical assets and financial assets to pay back their old debts (Shleifer and Wishny, 1992; Lang et al, 1995). However, a debt-eq- 
uity swap is another way to help debtors with cash shortages to reduce the burden of immediate repayment and therefore not to have to seek measures to get cash immediately to repay the debt, like selling assets. Debtors can negotiate with creditors for a debt-equity swap in a way that pays only part of their debt immediately, while the remaining debt will be settled with future payments (Gilson et al, 1990). The advantage of equity liabilities for the debtor is that smaller dividends may be paid if the revenue produced by an equity investment declines or the dividends may only be payable in a few years time. The debt-equity swap which increases profitability (Senbet and Seward, 1995; Banerii, 2008; Schultz and Braund, 2011) and company creditworthiness can also help companies to boost their bond ratings or change their capital structure to take advantage of current stock valuations.

As for both the debtor and creditor, the key issue to consider would be the structure of the swap. The lender may want the shares to be redeemable, for example near the end of a term loan (Bristow, 2009). However, banks need to consider this method carefully and comprehensively because they may lose their previous advantage when changing roles from creditors to becoming shareholders (Wang, 2016). In addition, the government's heavy influence in the financial sector could easily compromise the market-based pricing mechanism such as the case of China (Fitch, 2016). Therefore, conducting a debt-equity swap requires the banks to apply some important criteria, such as creating strict viability and eligibility criteria for corporations, having sound corporate governance, limiting the scope and time of the banks'ownership of the equity, converting the debt at fair value, and recognizing losses (Daniel et al, 2016).

\section{Securitization}

Securitization is the financing or re-financing of income-yielding assets by packaging them into a tradeable form through the issue of bonds or other securities (International Finance Corporation (IFC), 2004). There are four principal participants in a securitization structure, including the (i) originator, (ii) issuer or purchase, (iii) managers, and (iv) investors or buyers of the asset-backed securities.

Securitization is divided into three main categories, namely true sale, synthetic and "whole business". In a true sale securitization, a company sells assets to a special purpose vehicle (SPV) (a company) which funds the purchase by issuing bonds to the capital markets. So, the underlying pool of loans is completely transferred out of the bank's balance sheet (Farrruggio and Uhde, 2015). In a synthetic securitization, the company does not sell any assets but transfers the risk of loss associated with some of its assets to an SPV or a bank against payment by such a company of a premium or fee to the SPV. "Whole business" securitization is essentially a secured loan granted by an SPV to the relevant company.

Another way of classification is based on the perspective of the cash flow. The three most common types of securitization structures are collateralized debt, passthrough and pay-through structures. With a collateralized debt, the owner of the assets borrows money and pledges the assets to secure repayment. The assets pledged may be measured according to their market value upon sale, or their ability to generate a cashflow stream. The debt instruments need not match the cash-flow configuration of any of the assets pledged. Pass-through securitiza- 
Gadjah Mada International Journal of Business - September-December, Vol. 22, No. 3, 2020

tion is the simplest way to securitize assets with a regular cash flow, by selling direct participation in the pool of assets. A paythrough debt instrument is a borrowing instrument. Under the pay-through structure, the assets are typically held by a limited purpose vehicle that issues debt collateralized by the assets.

According to International Finance Corporation (2004), securitization is considered to be a highly efficient tool for diversification by investors and originators. For a commercial bank, securitization brings a number of benefits, such as raising funds, limiting credit exposure to assets, improving balance sheet efficiency, tapping different funding sources, reducing funding costs and matching assets and liabilities. IFC (2004) also lists many key conditions for securitization transactions, including: (i) key requirements for a legal system; (ii) typical securitization structures; (iii) accounting treatment; (iv) impact of Basel II; (v) taxation aspects of securitization transactions; (vi) role of the rating agencies and (vii) parties and their roles.

However, off-balance sheet strategies may impact on bank income, capital or coverage ratios. In particular, selling loans whose impairment levels are lower may have this effect. To be precise, a bank, as an originator, can gather different loans which it does not want to service anymore into a reference portfolio and then sell the latter to an issuer. This means that a bank can move debt into a securitized porfolio, leading to an reduction in the amount of liabilities held on its balance sheet, or contributing to free up capital for an originator (a bank). With the new funds raised, a bank can develop its lending activities and transfer credit risk to third parties. As a result, securitization can have positive impacts on bank incomes, capital or coverage ratios (Comptroller of the Currency, 1997).

\section{Liquidation of collateral}

Collateral is an asset that borrower offers to lenders in order to secure loans. If the borrower fails to repay the loans within a reasonable time, the lender can liquidate the guaranteed asset to recover the loans (or losses) partially or totally. So, the liquidation of collateral is the lender's action of selling guaranteed assets when borrowers are not able, or refuse, to execute their obligations related to paying interest and the principal.

In order for it to be feasible for handling non-performing loans, the liquidation of collateral requires a complete legal framework that indicates in more detail the regulations related to the reasonable time-periods for giving notice of the sale, the rights and obligations of the concerned parties, as well as offering lenders the right to seize collateral (Duong and Nguyen, 2017). In addition, debtors should also be protected against secured creditors by being allowed to have an appropriate reorganization period (Fabbri and Menichini, 2009).

\section{Non-performing loan write-offs by loan loss reserves}

Before using this method, it is necessary to classify all the loans to assess which loans are considered NPLs. According to Golin and Delhaise (2013), loan loss provisions can be a general provision or a specific provision. The general provision is used to handle all loans that are not yet determined to be bad loans, although the issuing banks believe that those loans have a high risk of default. The specific provision is used for loans that are determined to be difficult to repay. Since 
banks do not expect all loans are fully repayable, they usually have a loan loss reserve fund to compensate for those losses when needed (Etinosa, 2016).

To establish the loan loss provision amounts, bank managers require regular screening of their bank's loan portfolios, ranking each asset (i.e. loan) or group of assets by market conditions, collateral conditions and other business risk factors. Loan loss provisions are constantly in need of updated estimates, based on the statistics for the bank's customer defaults, preferable using for prudential purposes (BSBC, 2015). As a part of this process, the banks are responsible for providing guidance regarding the accounting method for credit losses, to ensure an adequate level of consistency across all entities (ECB, 2016). The timely recognition of provisions and the write-off of unrecoverable loans are important for the banks, as they serve to strengthen their balance sheets and enable them to (re)focus on their core business, most notably lending to the economy (ECB, 2016; BSBC, 2015; IMF, 2014). Therefore, banks should determine suitable maximum periods for full provisioning and

Table 1: Necessary conditions for implementing NPL resolutions described in the previous research

\begin{tabular}{|c|c|c|c|c|}
\hline Conditions & $\begin{array}{l}\text { Debt-to-Equity } \\
\text { Swap }\end{array}$ & $\begin{array}{l}\text { NPL Write-Offs by } \\
\text { Loan Loss Reserves }\end{array}$ & Securitization & $\begin{array}{l}\text { Liquidation of } \\
\text { Collateral }\end{array}$ \\
\hline Regulations & & $\begin{array}{l}\text { Merritt (2016); Garcia } \\
(2016)\end{array}$ & IFC (2004) & $\begin{array}{l}\text { Duong and Nguy- } \\
\text { en (2017) } \\
\text { Fabbri and Men- } \\
\text { ichini (2009) }\end{array}$ \\
\hline $\begin{array}{l}\text { Pricing mechanism and } \\
\text { role of valuation organi- } \\
\text { zation }\end{array}$ & $\begin{array}{l}\text { Fitch (2016) } \\
\text { Daniel et al } \\
(2016)\end{array}$ & & IFC (2004) & $\begin{array}{l}\text { Duong and Nguy- } \\
\text { en (2017) }\end{array}$ \\
\hline Role of creditors & $\begin{array}{l}\text { Daniel et al } \\
(2016)\end{array}$ & $\begin{array}{l}\operatorname{IMF}(2014) \\
\operatorname{BSBC}(2015) ; \\
\text { ECB (2016); }\end{array}$ & IFC (2004) & $\begin{array}{l}\text { Duong and Nguy- } \\
\text { en (2017) }\end{array}$ \\
\hline Role of debtors & Moye (2001) & & IFC (2004) & $\begin{array}{l}\text { Duong and Nguy- } \\
\text { en (2017) }\end{array}$ \\
\hline Characteristics of solutions & $\begin{array}{l}\text { Bristow (2009) } \\
\text { Wang (2016) }\end{array}$ & & IFC (2004) & \\
\hline Accounting & $\begin{array}{l}\text { Daniel et al } \\
\text { (2016) }\end{array}$ & $\begin{array}{l}\text { BSBC (2015); } \\
\text { Etinosa (2016); } \\
\text { Merritt (2016); Garcia } \\
\text { (2016); }\end{array}$ & $\begin{array}{l}\text { IFC (2004) } \\
\text { Farrruggio and } \\
\text { Uhde (2015) }\end{array}$ & \\
\hline Rating agencies & & & IFC (2004) & \\
\hline Taxation aspects & & & IFC (2004) & \\
\hline $\begin{array}{l}\text { Macroeconomic environ- } \\
\text { ment }\end{array}$ & & & IFC (2004) & \\
\hline
\end{tabular}

GAAP rules (Merritt, 2016; Garcia, 2016). The banks need to determine what loan loss provision amounts are adequate, as well as to reassess and increase provisioning levels write-offs (ECB, 2016). The banks should follow the write-off procedures, which are in accordance with best practices issued by such institutions as the IMF or BCBS. 


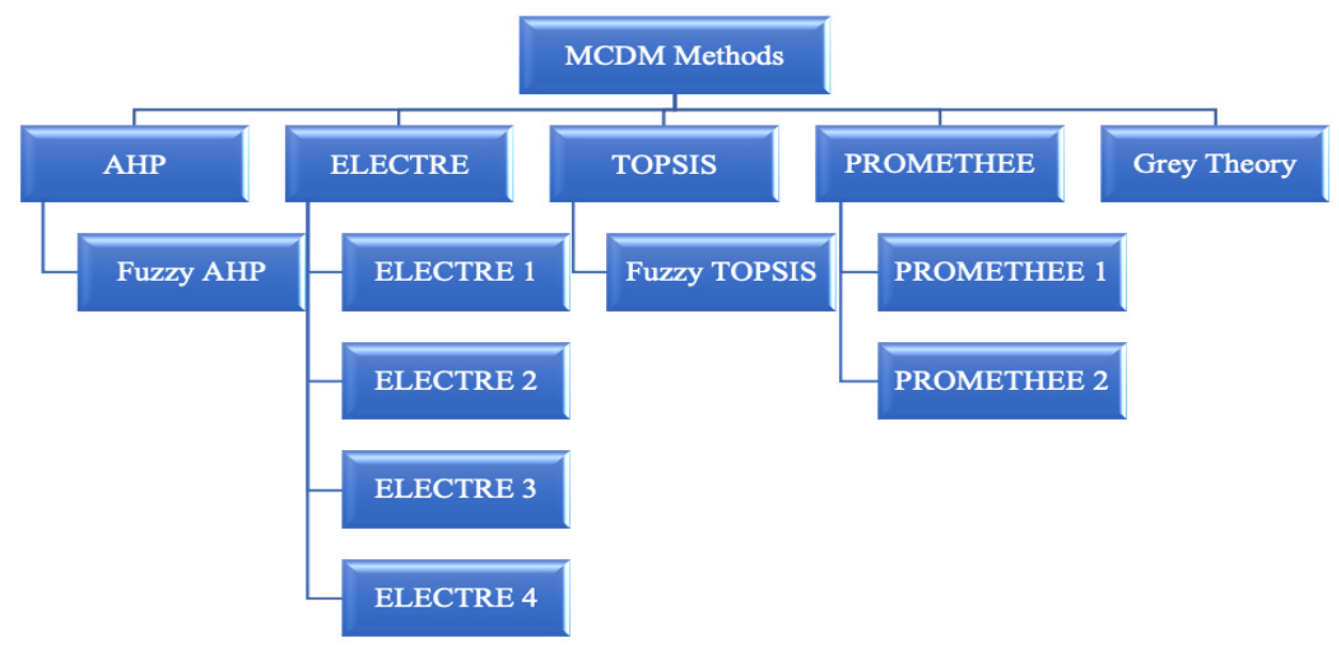

Figure 1: Hierarchical structure of MCDM methods Source: Aruldoss et al (2013)

\section{AHP, TOPSIS methods and their applications}

In terms of methodologies, multiple-criteria decision-making $(\mathrm{MCDM})$ is considered an effective tool for finding the best alternative complex options with a number of criteria and options, which is pretty appropriate to this research's objective of evaluating solutions dealing with NPLs through evaluation criteria or the necessary conditions for implementing these solutions. In fact, the MCDM method is a powerful technique for decision making (Aruldoss et al, 2013). Managers take decisions by simultaneously considering all the criteria (including both quantitative and qualitative factors) and objectives, by using MCDM. Figure 1 describes different types of MCDM methods. Among the various types of MCDM methods, the analytic hierarchy process (AHP) has experienced many applications in a number of economic sectors. It is based on the priority theory. Experts give an opinion or evaluation for each alternative by considering different criteria. Then, AHP uses the comparison process to explain the experts' preferences. An $\mathrm{m}^{*} \mathrm{n}$ matrix is con- structed with " $m$ " alternatives and " $n$ " criteria. So, AHP allows people to deal with complex choices, which involve the simultaneous consideration of multiple-criteria and alternatives.

In the field of banking, MCDM methods are becoming popular for various applications, such as banking performance, performance evaluation or e-bankings' development. Using a fuzzy set and fuzzy numbers simultaneously, FAHP and TOPSIS, YalcinSecme et al (2007) analyzed the performance of the Turkish banking sector in terms of both financial and non-financial criteria. Their research aimed to find out the key factors for improving the performance of the banking system, since the economy was changing rapidly. Commercial banks were evaluated for their customer satisfaction and service qualities (YalcinSecme et al, 2017). In the same research field, some researchers like Wu et al (2011) used SAW , TOPSIS and "VIseKriterijumska Optimizacija I Kompromisno Resenje" (VIKOR) in order to evaluate banking performance based on the balanced scorecard with four criteria such as finance, customer, internal process, learning and growth. 
Anh et al

\section{Methods}

\section{Research design and data collection}

Before assessing the four main methods of dealing with non-performing loans in Vietnam, including the write-off of non-performing loans by loan loss reserves, the liquidation of collateral, debt-to-equity swaps and securitization, this research tried to find the evaluation criteria. Based on the literature in a state agency and commercial banks in Hanoi. The in-depth interviews allowed the researchers to explore the experts' perspectives about the criteria that this assessment should be based on, as well as their content and components. Then, the authors decided to divide the multiple criteria into four groups: (i) the legal framework, (ii) main parties, (iii) intermediates, and (iv) market-specific conditions [Table 2].

Table 2: NPL resolutions and criteria for assessment

\begin{tabular}{|c|c|c|c|c|}
\hline Methods Criteria & Legal Framework & Main Parties & Intermediates & $\begin{array}{l}\text { Market- specific } \\
\text { Conditions }\end{array}$ \\
\hline $\begin{array}{l}\text { NPL Write-Offs by } \\
\text { Loan Loss Reserves } \\
\text { Liquidation of Col- } \\
\text { lateral } \\
\text { Debt-to-Equity Swap } \\
\text { Securitization }\end{array}$ & $\begin{array}{l}\text { Complete Regulations } \\
\text { related to transaction } \\
\text { process, rights of } \\
\text { each party. }\end{array}$ & $\begin{array}{l}\text { Issuers: Liquidity po- } \\
\text { sition, risk exposure, } \\
\text { regulatory capital arbi- } \\
\text { trage, performance } \\
\text { Investors: perfor- } \\
\text { mance }\end{array}$ & $\begin{array}{l}\text { Rating Agen- } \\
\text { cies } \\
\text { Investment } \\
\text { Bank }\end{array}$ & $\begin{array}{l}\text { Market competition } \\
\text { Macroeconomic } \\
\text { environment }\end{array}$ \\
\hline
\end{tabular}
Source: Authors

review described in the second part of this paper, the authors proposed certain ideas and discussed about how to assess the resolution of NPLs, with three managers who worked
Moreover, the authors did pilot testing during the in-depth interviews, in order to identify if the respondents understood the questionnaire, if they had any comments

Figure 2: Research model

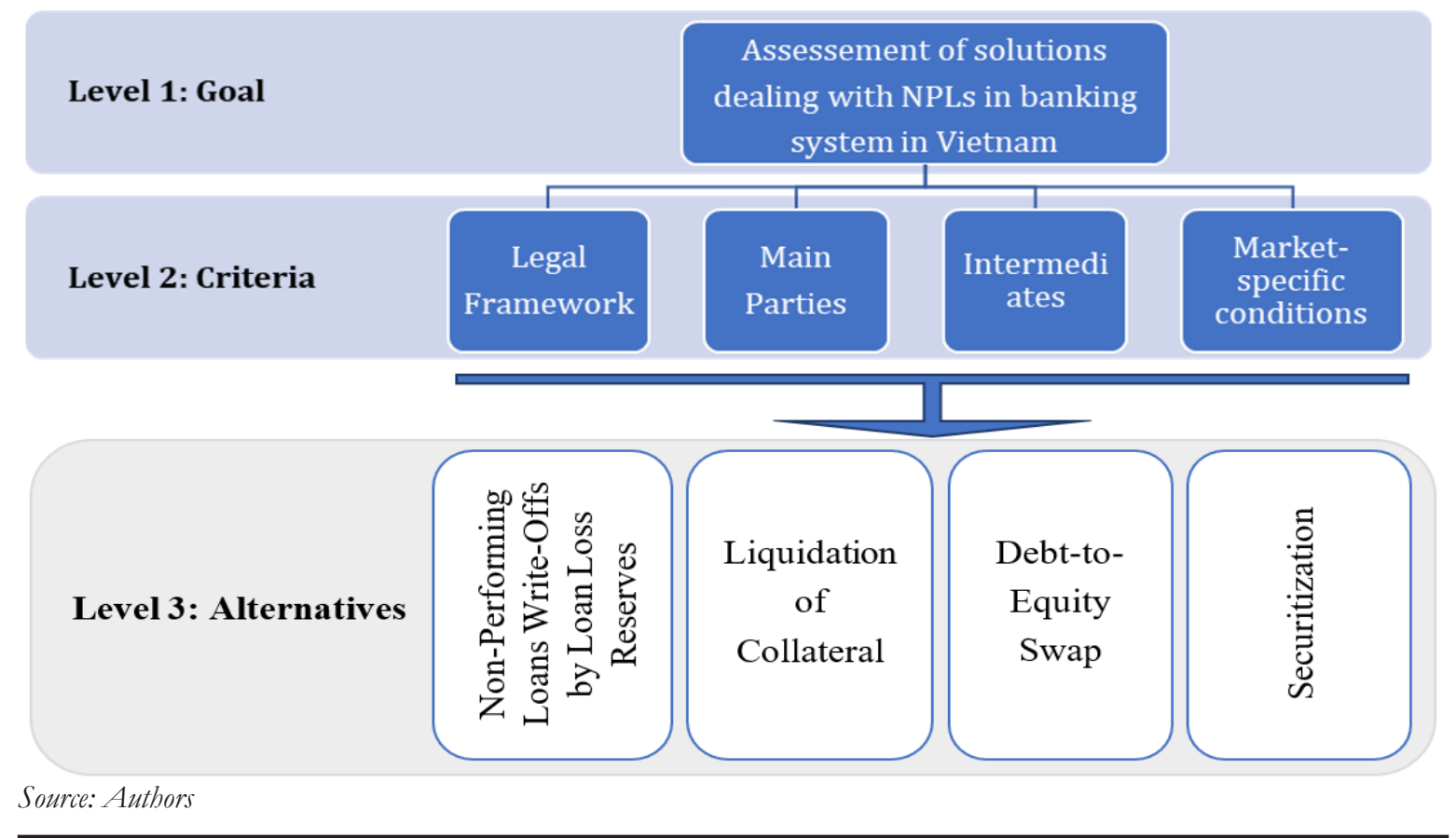


about both the content and format of the survey or any suggestions in order to make the survey clearer and more significant. Based on the sample group's feedback about their understanding of, and concerns about, the questions, the authors made the necessary adjustments and amendments in order to make sure that the questions had face validity. To ensure the accuracy of the responses, the researchers used various kinds of questions including closed-ended and open-ended questions, as well as Likert scale questions with a four-point scale which allowed each individual to express how much they agree or disagree with a particular statement, by numbering from 1 , the lowest (the worst), to 4 , the highest (the best).

In fact, the survey included 18 questions, which were divided into four main criteria as follows: there were five questions for each of critera 1 and 2, four questions for criterion 3 and two questions for criterion 4. Moreover, two final questions were used to recheck the coincidence of answers for the previous questions. After that, the authors sent the survey to nine experts, with 20 years of working experience (on average), who were state agency managers and commercial bank managers, to solicit their professional opinions. Figure 2 presents in more detail the research design.

\section{Methods of Data Analysis}

In order to calculate the weight of each alternative, the research uses the analytic hierarchy process (AHP). This has five main steps: (i) Calculate the average weight of each criterion. (ii) Establish the pairwise comparison matrix of the criteria, the relative reciprocal matrix of the criteria, and calculate the EBQ ranking vector for the criteria. (iii) Check the consistency of the judgments. (iv)
Establish the pairwise comparison matrix of alternatives for each criterion, the relative reciprocal matrix of alternatives with respect to each criterion by using the numeric scale, and calculate the EBQ ranking vector of alternatives for each criterion $\left(E B Q_{j i}\right)$; (v) Calculate the value of each alternative; the higher the value the better it is. The AHP's detailed steps are described in Appendix 1.

In addition, the research also aimed to rank the resolution of NPLs by using a fuzzy TOPSIS approach, including eight distinct steps: (i) Calculate the fuzzy rating of the decision maker about alternatives to the criterion. (ii) Calculate the aggregated fuzzy ratings for the alternatives. (iii) Compute the normalized fuzzy decision matrix. (iv) Compute the weighted normalized fuzzy decision matrix. (v) Compute the fuzzy positive ideal solution (FPIS $-A^{+}$) and fuzzy negative ideal solution (FNIS - $A^{-}$). (vi) Calculate the distance from each alternative $A_{i}$ to the FPIS $\left(d_{i}^{+}\right.$and to the FNIS ( $d_{i}^{-}$; (vii) Calculate the closeness coefficient $C C_{i}$ for each alternative $A_{i}$. (viii) Rank the resolution of the NPLs in descending order. The detailed different steps for the fuzzy TOPSIS are illustrated in Appendix 2.

\section{Results}

The research showed the consistency ratio to be (0.09) - less than 0.10 [Appendix 6]. This means it is acceptable to continue with the AHP analysis. According to the AHP analysis, it was clear that the overall priorities of all the alternatives were quite low. In other words, non-performing loans were not dealt with effectively in previous years in Vietnam.

To be more precise, the interviewed experts gave their assessements about the importance of the criteria. Table 3 shows that the legal framework and directly concerned 
parties were considered the greatest factors that influenced the performance measures banking system in Vietnam, compared to the other three methods [Table 3].

Table 3: Synthesis of the model

\begin{tabular}{|c|c|c|c|c|c|c|}
\hline & & $\begin{array}{l}\text { Legal Frame- } \\
\text { work } \\
\text { (C1) } \\
\mathbf{0 . 2 9}\end{array}$ & $\begin{array}{l}\text { Intermediary } \\
\text { Parties } \\
\text { (C2) } \\
0.24\end{array}$ & $\begin{array}{l}\text { Directly } \\
\text { Concerned } \\
\text { Parties } \\
\text { (C3) } \\
\mathbf{0 . 2 8}\end{array}$ & $\begin{array}{l}\text { Market Con- } \\
\text { ditions } \\
\text { (C4) } \\
0.20\end{array}$ & Value \\
\hline A1 & $\begin{array}{l}\text { Non-Performing Loans } \\
\text { Write-Offs by Loan Loss } \\
\text { Reserves }\end{array}$ & 0.33 & 0.30 & 0.28 & 0.34 & 0.3096 \\
\hline A2 & Liquidation of Collateral & 0.27 & 0.25 & 0.23 & 0.27 & 0.2552 \\
\hline A3 & Debt - Equity Swap & 0.23 & 0.24 & 0.27 & 0.21 & 0.2398 \\
\hline A4 & Securitization & 0.17 & 0.21 & 0.22 & 0.17 & 0.1954 \\
\hline
\end{tabular}

(0.29 and 0.28 , accordingly) while the last position belonged to market conditions with 0.20 . However, the differences in the weights of the criteria were insignificant. In terms of different methods for dealing with bad debts, non-performing loans' write-offs by loan loss reserves had an overall priority of 0.3096 - which ranked in the first place. The liquidation of collateral (0.2552) and debt-equity swaps $(0.2398)$ were less effective solutions in comparison with the first alternative. The worst effective alternative was securitization. In other words, given the importance (or weight) of the criteria (including the le-
The above results were totally consistent with the fuzzy TOPSIS approach. Based on the closeness coefficient for each alternative in Table 4, the research classed A1 in first place with the biggest CC of 0.4646 , while A4 had the smallest CC of 0.02771 . Next to A1 was A2, with a CC of 0.3664 , and then A3 with a CC of 0.3096. In other words, the most effective method of dealing with bad debts was writing-off non-performing loans with loan loss reserves. Liquidating collateral and a debt-equity swap were ranked in second and third places, acccordingly. The worst effective solution was securitization.

Table 4: The closeness coefficient for each alternative and the descending order of NPLs resolutions

\begin{tabular}{|c|c|c|c|c|}
\hline Alternatives & $\begin{array}{l}\text { A1: Non-Performing Loans } \\
\text { Write-Offs by Loan Loss } \\
\text { Reserves }\end{array}$ & $\begin{array}{l}\text { A2: Liquidation of } \\
\text { Collateral }\end{array}$ & $\begin{array}{l}\text { A3: Debt - Equity } \\
\text { Swap }\end{array}$ & A4: Securitization \\
\hline$d+$ & 1.9850 & 2.2596 & 2.4813 & 2.7900 \\
\hline d- & 1.7227 & 1.3066 & 1.1127 & 1.0694 \\
\hline $\mathrm{CC}$ & 0.4646 & 0.3664 & 0.3096 & 0.2771 \\
\hline Rank & 1 & 2 & 3 & 4 \\
\hline
\end{tabular}

Source: Authors

gal framework, intermediary parties, directly concerned parties and market conditions), the alternative number one is the most effective solution for dealing with NPLs in the
These results, extracted from AHP and fuzzy TOPSIS, totally agreed with the answer to Question No.17 where authors asked the dicision-makers about the priority of choos- 


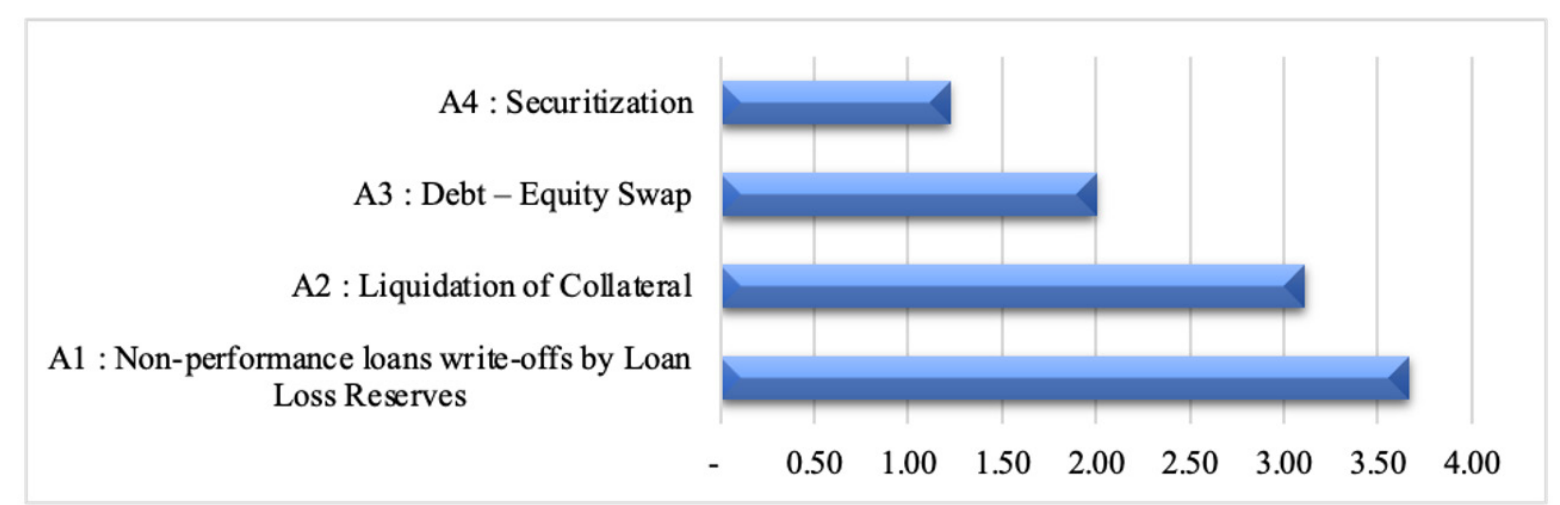

Figure 3: Priority of choosing solutions for dealing with NPLs in the Vietnamese banks in the previous years Source: Authors

ing solutions for dealing with NPLs in the Vietnamese banks in the previous time [Figure 3].

In terms of local priorities, Table 5 also shows what the priorities of the alter- analysis allows for an understanding of how robust the original decision was, and which criteria influenced the original results. So, the researchers made changes to the weight of each criterion. In detail, this research analyzed a scenario where all the criteria have the

Table 5: Synthesis of the model in a scenario where all the criteria have the same weight

\begin{tabular}{|c|c|c|c|c|c|c|}
\hline & & $\begin{array}{l}\text { Legal Frame- } \\
\text { work } \\
(\mathrm{C} 1) \\
0.25\end{array}$ & $\begin{array}{l}\text { Intermediary } \\
\text { Parties } \\
(\mathrm{C} 2) \\
0.25\end{array}$ & $\begin{array}{l}\text { Directly } \\
\text { Concerned } \\
\text { Parties } \\
\text { (C3) } \\
025\end{array}$ & $\begin{array}{l}\text { Market Con- } \\
\text { ditions } \\
(\mathrm{C} 4) \\
025\end{array}$ & Value \\
\hline A1 & $\begin{array}{l}\text { Non-Performing Loans } \\
\text { Write-Offs by Loan Loss } \\
\text { Reserves }\end{array}$ & 0.33 & 0.30 & 0.28 & 0.34 & 0.3115 \\
\hline A2 & Liquidation of Collateral & 0.27 & 0.25 & 0.23 & 0.27 & 0.2563 \\
\hline A3 & Debt - Equity Swap & 0.23 & 0.24 & 0.27 & 0.21 & 0.2375 \\
\hline A4 & Securitization & 0.17 & 0.21 & 0.22 & 0.17 & 0.1945 \\
\hline
\end{tabular}

natives are, with respect to the legal framework, intermediary parties, and the directly concerned parties'market conditions. Obviously, there is no big gap between the local priorities. This meant that all four criteria played the same important role in the effectiveness of the different methods for dealing with non-performing loans in the banking system in Vietnam. This remark is also justified by the sensitivity analysis. This research used sensitivity analysis to see how the final results would have changed if the weights of the criteria were different. The sensitivity same weight. Table 5 shows the new result in comparison with the original model.

In detail, market conditions were the key factors contributing to the success of the first two alternatives $(0.34$ and 0.27 for alternative 1 and alternative 2, accordingly). Following the market conditions was the legal framework, then intermediary parties and finally the directly concerned parties. In contrast, the directly concerned parties played the most important role in the effectiveness of the two last alternatives (0.27 and 0.22). 
The closest to the directly concerned parties were the intermediary parties. Conditions related to the legal framework and market conditions were not good, so debt-equity swaps and securitization were not previously effective for dealing with non-performing loans in the banking system in Vietnam .

\section{Discussion}

Using the AHP and TOPSIS methods, this research evaluated the effectiveness of the NPL solutions implemented in Vietnam and found that in recent years, the Vietnamese banking system was not able to completely solve its bad debt problem. This result of this research is totally in agreement with the reports issued by the National Financial Supervisory Commission at the end of 2017 (NFSC, 2017), and 2018 (NFSC, 2018).

The research showed that NPL writeoffs with loan loss reserves and the liquidation of collateral, as well as debt-equity swaps, were the most popular methods for resolving NPLs, and were implemented by many of the banks in Vietnam. This result is consistent with the fact that the risk provisioning ratio of Vietnamese banks has increased frequently in the past two years. Specifically, in the first half of 2018 , many banks used up to $50 \%$ of their profits to increase their risk provisions, and then used them to deal with bad loans (Don, 2018). This was because many banks decided to resolve their NPLs by any means possible, even though only part of the principal may be recovered (Linh, 2016). Another reason why many banks had to increase their risk provision was that, although Vietnam's economy was growing well, recent economic shocks forced the banks to be more cautious. It can be said that the banks spent large amounts of their profits on their risk provisions, to prevent potential risks in the future and also to help them be more active in dealing with bad debts (Lien, 2017). The findings of this paper are similar to the results of many other previous studies, such as those by the ECB (2016), BSBC (2015), and the IMF (2014). In the world, NPL write-offs are one of the most popular and simplest measures to deal with bad debt, but banks often do not want to apply this method because it directly affects their capital and profits. However, in times off crisis, this measure can be considered as an urgent solution (BIS, 2017). As in the recent global financial crisis, countries like the US, Japan or some European countries used this method. Specifically, the governments of these countries required banks to write-off NPLs that had a low recovery capacity (IMF, 2015). On the other hand, the low loan loss reserves are also a hindrance when banks want to write-off NPLs, because their reserves are not enough to absorb these losses. The very low reserve ratios of US and European banks only permitted the write-off of a few NPLs during the last financial crisis (Ingves, 2011).

Debt-equity swaps are also considered to be a measure to handle bad debts, which Vietnamese banks have applied, despite being ranked third among the NLP solutions analyzed by this research. This result is also appropriate because the Government of Vietnam is encouraging its financial institutions to apply debt-equity swaps to handle their bad debts (Government of Vietnam, 2017). If a bank is not allowed to swap its bad debt for equity, the bad debt still remains at the bank and its bad debt ratio is still high. In other words, debt-equity swaps are better for the banking system, and the economy of Vietnam as a whole, rather than the banks making new loans to reverse bad debts, or only using technical measures to remove bad debts from their balance sheets, instead 
of actually handling these bad debts (Ngoc, 2016). The implementation of debt-equity swaps in Vietnam shows that this measure is effective in dealing with the bad debts of enterprises in temporary distress. In some cases debt-equity swaps have helped Vietnamese businesses facing the possibility of bankruptcy to obtain the resources necessary to restore their production and business activities (Phuong, 2018).

Although securitization is considered an effective tool to deal with NPLs in developed countries, such as the United States, South Korea or developing countries like China, Malaysia and Thailand, this research's findings indicate that in Vietnam, securitization is the last method that banks should use to handle their bad debts. This conclusion is consistent with the actual situation where many NPLs are transferred from commercial banks to the Vietnam Asset Management Company (VAMC), to keep the percentage of NPLs low on the banks' balance sheets, while the NPLs are just held by this organization without being securitized.

The empirical results, however, emphasize that there is an upward trend in the use of various solutions for dealing with bad debt in the coming years in Vietnam [Figure 3]. In terms of the criteria, the result of this research shows that the legal framework and directly concerned parties play the most crucial roles in the success of the methods for dealing with NPLs in Vietnam. In fact, the legal framework mentions regulations related to transaction processes and the rights of each party; the directly concerned parties include banks, borrowers and investors. Therefore, the authors propose some policy implications as follows:

Firstly, Vietnam should pay more attention to resolutions like debt-equity swaps and securitization, because the use of such traditional measures for write-offs by loan loss reserves and the liquidation of collateral, as implemented recently, cannot completely solve the NPL problems of the Vietnamese banking system. It means that the banking system in Vietnam should focus on completing the legal framework and encouraging market conditions.

Secondly, it is obviously to see that the liquidation of collateral is ranked in 2 nd place but its overall use is still low. The liquidation of collateral takes a lot of time, because according to current regulations in Vietnam, there are many steps to selling collateral and most of the borrowers do not cooperate when handling debts. In addition, the credit institutions are obligated to wait for a court decision before carrying out the subsequent appropriate steps. This causes the credit institutions to spend too much time waiting for such decisions, so they face the risk of a decrease in the asset's value when it is finally allowed to be sold. Therefore, it is necessary to make changes to the regulations in order to simplify and speed up the process of liquidating collateral. Moreover, the credit institutions should have measures to ensure and also regulate, in the security contract, that (i) the collateral is not the subject of a dispute with any party; and (ii) the consent of all the co-owners or relevant parties (if any) is obtained to use the asset as a security measure in the security contract.

Thirdly, although debt-equity swaps are the third-best solution out of the four NPL resolutions implemented by the Vietnamese banking system, this solution is ranked first in other countries such as China. The cause of this situation is that many Vietnamese banks are concerned that when they become shareholders, they may not be able to effec- 
tively manage the business because they are not knowledgeable enough about the area in which the enterprise operates. In addition, because of the limited resources of some banks, as well as the large scale of bad debts, it is difficult for the banks to persuade their shareholders to use debt - equity swaps to handle the NPLs. The empirical results show that the legal framework and market conditions need to be enhanced in the near future, should Vietnam plan to introduce debt-equity swaps as an instrument for dealing with NLPs.

Last but not least, there is a great upward trend for the use of securitization over the next few years, which is clearly shown in Figure 4. Considering the very low local desire for this solution, Vietnam should focus on all four key conditions in general, and on improving the legal system in particular, to assure the success of securitization in the coming years.

In order to achieve this purpose Vietnam should refer to the international practices identified by the IFC's research including: (i) Only assets capable of being transferred can be securitized. (ii) The sale and transfer of securitized assets should be irreversible. (iii) The transfer should not be overly costly or cumbersome. (iv) Effecting the assignment of receivables without notification to the obligor should be possible. (v) The purchaser should be able to efficiently enforce ownership rights, with respect to securitized assets, and should be allowed to appoint a back-up servicer if necessary. (vi) The parties should be able to enter into effective security arrangements, to provide credit enhancements, mitigate coming risk and/or install a security trustee. (vii) Limited recourse provisions and competition covenants agreed between the parties should be enforceable. (viii) Subordination arrangements should be enforceable (IFC, 2004).

In addition, experiences from both developed countries (such as the United States and South Korea) and developing countries (such as China, Malaysia and Thailand) show very strongly that it is necessary to improve the legal framwork for securitization, supervise strict relationships among the main parties involved in the securitization process, support the intermediary institutions and improve the conditions related to the financial markets. In terms of the intermediary parties, the priority for this securitization criterion is only 0.21 , while for securitization activities, the rating agencies - which are important intermediary parties - play an integral role and have a considerable degree of input in respect of how cash flows and the legal framework are structured. Rating agencies' opinions are very important for pricing most asset-backed securities and so for attracting attention from investors. Therefore, in the next few years, Vietnam should encourage independent rating agencies to develop. In case there are no competent domestic rating agencies, it would be necessary to accept and allow the participation of foreign rating agencies in Vietnam. So, Vietnam should implement policies and regulations to attract more reputable international rating agencies to operate in Vietnam.

\section{Conclusion}

This research has achieved its objective of assessing the effectiveness of the non-performance loan handling solutions implemented in Vietnam in recent times. The study applied the analytical hierarchy process (AHP) and the technique for order preference by similarity to ideal solution (TOPSIS) to develop evaluation criteria to use as a basis for designing survey forms to interview 
nine experts with over 20 years experience of working in the field of state management and banking to evaluate and prioritize the NPL solutions to be implemented in Vietnam. This is the first time that solutions for handling NPLs in Vietnam have been evaluated using the criteria built on the two above-mentioned methods. The research's results indicate that NPLs write-offs by loan loss reserves and the liquidation of collateral are the two most frequently used methods by Vietnamese commercial banks. The bad debt ratio of the Vietnamese banking system has steadily decreased over the years from $4.08 \%$ in 2012 to $2.4 \%$ in 2018 , showing that those two measures for handling bad debts are relatively effective. However, the bad debt issue has not been completely resolved. On the other hand, the market-based measures to handle NPLs, such as debt-equity swaps and securitization are still rarely applied. This shows that Vietnam needs to strengthen the combination of traditional bad debt handling solutions (such as NPLs write-offs by loan loss reserves and the liquidation of collateral) with market-based solutions (such as debt-equity swaps and securitization) in the coming period. The empirical results are also the basis for the authors to propose a number of recommendations, so Vietnam is able to implement market-based solutions to address the NPL problem in its banking system.

The limitation of this study is the data collected for use by this research. According to the AHP and TOPSIS methods, the data are taken from in-depth interviews with experts. Although the experts selected in this study were those who had extensive experience working in the field of state management and banking, because the number of experts was limited, their comments may not be comprehensive and objective enough. Therefore, there is a need for further follow-up studies with a richer sample of data, collected from more market participants, such as investors, state agencies and bank managers. The results of such studies can better assess the effectiveness of the applied NPL solutions, as well as provide highly feasible specific recommendations to thoroughly solve the NPL problems of the Vietnamese banking system.

\section{References}

Akiko Terada-Hagiwara, Gloria Pasadilla. (2004). Experience of Asian asset Management Companies: Do They Increase Moral Hazard? Evidence From Thailand. ERD Working Paper Series No.55.

Aruldoss M., Lakshmi T.M., Venkatessan V.P. (2013). A survey on multi criteria decision making methods and its applications. American Journal of Information systems.

Banerji, S. (2008). Asset sales and debt-equity swap under asymmetric information. Economic Letters 99, 189-191.

BIS. (2017). Resolution of non-performing loans - policy options. Bank for International Settlement.

Barisitz, S. (2011). Non Performing Loans in CESEE: What do they comprise? Focus on European Economic Intergration, 46-68.

Barisitz, S. (2012). Non-Performing Loans in Western Europe: A comparison of Countries and 
National Definitions. Focus on European Economic Intergration, 28-47.

Barisitz, S. (2013). Non-Performing Loans in CESEE: An Even Deeper Definitions Comparision. Focus on European Economic Intergration, 64-81.

Bristow. (2009, July 17). Debt/Equity Swaps: All the Rage. Retrieved October 7, 2017, from https:// www.bristows.com/news-and-publications/articles/debt-equity-swaps-all-the-rage/

BSBC. (2015). Guidance on credit risk and accounting for expected credit losses. Retrieved October 25, 2017, from http://www.bis.org/bcbs/publ/d311.pdf

Bulloch, D. (2016, June 17). Retrieved June 9, 2018, from China's playing hot potato with its non-performing loans: https://www.forbes.com/sites/douglasbulloch/2016/06/17/chinas-playing-hot-potato-with-non-performing-loans/\#17f93f6a2699

Comptroller of the Currency (1997). Asset Securitization. Retrieved fromhttps://www.occ.treas. gov/publications-and-resources/publications/comptrollers-handbook/files/asset-securitization/index-asset-securitization.html

Daniel, J., Garrido, J., Moretti, M. (2016). Debt-Equity Conversions and NPL Securization in China Some Initial Considerations. NY: IMF.

Don, H. (2018, August 17). Retrieved November 22, 2018, from https://vietstock.vn/2018/08/ tang-du-phong-de-xu-ly-nhung-no-xau-cua-ngan-hang-van-tang-757-623664.htm

Duong Q.T., Nguyen T. H. (2017). Right to size collateral in trading and handling bad debts. Dimac-Professional Corporate Laywers.

ECB. (2017). Guidance to banks on non-performing loans. Frankfurt am Main, Germany: European Central Bank.

ECB. (2016). Draft guidance to banks on non-performing loans. Frankfurt am Main, Germany: European Central Bank.

Etinosa, E. (2016, June 19). Understanding loan loss provisioning for banks. Retrieved October 25, 2017, from https://www.linkedin.com/pulse/understanding-loan-loss-provisioning-banks-egharevba

Fabbri D., Menichini A.M.C. (2009). Trade credit, Collateral Liquidation and Borrowing Constraints. Working paper N.146. Centre for Studies in Economics and Finance. Retrieved February 12, 2019, from http:/ /www.csef.it/WP/wp146.pdf

Farruggio C., Uhde A. (2015). Determinants of loan securitization in European banking. Journal of Banking \& Finance(56), 12-27.

Fitch. (2016). Debt-For-Equity Swaps Leads to More Questions than Answers. Retrieved October 7, 2017, from https://www.fitchratings.com/site/dam/Fitch-on-China-Nov-2016.pdf

Garcia, M. (2016). How is Provision for Bad Debt Calculated. Retrieved October 25, 2017, from http:// smallbusiness.chron.com/provision-bad-debt-calculated-80681.html 
Gadjah Mada International Journal of Business - September-December, Vol. 22, No. 3, 2020

Gilson, S.C., John, K., Lang, L. (1990). Troubled debt restructurings: an empirical study of private reorganization of firms in default. Journal of Financial Economics 27, 315-353.

Golin, J. \& Delhaize, P. (2013). The Bank Credit Alanysis Handbook: A guide for Analysts, Bankers and Investors, 2nd edition. Singapore: John Wiley \& Sons Singapore Pt. Ltd.

Government of Nova Scotia. (2005, July 5). Budgeting and Financial Management Manual. Retrieved October 25, 2017, from https://novascotia.ca/treasuryboard/manuals/PDF/200/2110302.pdf

Government of Vietnam. (2017). Quyết định số 1058/QĐ-TTg về việc phê duyệt đề án Tái cơ cấu hệ thống các tổ chức tín dụng gắn với xử lý nợ xấn giai đoạn 2016-2020. Ha Noi, Vietnam.

Katia D'Hulster, Raquel Letelier, Valeria Salomao-Garcia L. (2014). Loan classification and provisioning: current practices in 26 countries. Washington D.C.: World Bank.

Ingves, S (2011): "Basel III - much-needed regulations for a safer banking sector", speech at the Swedish Society of Financial Analysts, February, Sveriges Riksbank.

IMF. (2014, September 15). Supervisory roles in Loan Loss provisioning in Countries implementing IFRS. Retrieved October 25, 2017, from https://www.imf.org/external/pubs/ft/wp/2014/ wp14170.pdf

IMF (2015): Global Financial Stability Report, Chapter 1: "Enhancing policy traction and reducing risks", April.

International Finance Corporation (IFC). (2004). Securitization Key Legal and Regulatory Issues. Global Financial Market Department.

Iwulska, A. (2012). Restructuring private debt: Republiic of Korea. Golden Growth Country Benchmarks. Washington, D.C.: World Bank.

Lang, L., Poulsen, A., Stultz, R. (1995). Asset sales, firm performance and agency costs of managerial discretion. Journal of Financial economics 37, 3-37.

Lien, T. (2017, November 4). Retrieved November 22, 2018, from http://ndh.vn/ngan-hangcan-rang-trich-nua-loi-nhuan-du-phong-rui-ro-20171104084514778p149c165.news

Linh, V. (2016, November 18). Retrieved November 22, 2018, from https://tinnhanhchungkhoan.vn/tien-te/ngan-hang-rao-riet-ban-no-giam-xu-ly-no-xau-bang-du-phong-169962.html

Merritt, C. (2016). GAAP Rules for Bad Debt. Retrieved October 25, 2017, from http:/ / smallbusiness.chron.com/gaap-rules-bad-debt-42598.html

Moye, M. (2001). Overview of Debt Conversion. London, UK: Debt Relief Internationall Ltd.

NFSC. (2018). The Financial Market Overview Report for 2018. Ha noi, Vietnam: National Financial Supervisory Commission.

NFSC. (2017). The Financial Market Overview Report for 2017. Ha noi, Vietnam: National Financial Supervisory Commission. 
Ngoc, P. M. (2016, October 18). Retrieved November 21, 2018, from http:/ / cafef.vn/hoan-doino-thanh-von-gop-co-phan-rat-can-thiet-2016101721443798.chn

Nolet, A. , Wong, C. (2017). Debt for Equity Swaps, a solution fo China”s NPL problems. Emerging markets and restructiring Journal, Issue 4.

Park, Y. C., Song, W. \& Wang, Y. (2006). Finance and economic development in Korea. Working Paper 0406. Seoul: Korea Institute for International Economic Policy.

Phuong, H. (2018, February 26). Retrieved November 21, 2018, from http://enternews.vn/ chuyen-no-xau-thanh-von-gop-ngan-hang-hay-doanh-nghiep-duoc-loi-125312.html

Saaty, T. (2012). Decision making for Leaders: The Analytic Hieracby Process for Decisions in a Complex World. Pittsburgh: RWS Publications.

Sach, J. (2009, March). Our Wall Street Besotted Public Policy. Retrieved October 7, 2017, from Real Clear Politics: https://www.realclearpolitics.com/articles/2009/03/making_rich_guys_ richer.html

Saoussen Ouhibi, Salma Ezzeddine and Algia Hammami. (2017). Non-performing Loans and Systemic Risk: Empirical Evidence to Tonisia and Morocco. Arabian Journal of Business and Management Review, 1-6.

SBV. (2005, April 22). Decisions No 493/2005/QD-NHNN on debt classifications, loan loss provision and the use of loan loss provision in dealing with credit risk in financial institutions operations. Retrieved October 25, 2017, from http://moj.gov.vn/vbpq/lists/vn\%20bn\%20php \%20lut/ view_detail.aspx?itemid $=18421$

Schultz \& Braund. (2011, December). Debt equity swap. Retrieved October 7, 2017, from https:// www.schubra.de/en/insolvencyadministration/esug/debt-equity_swap.php

Senbet, L., Seward, J. (1995). Financial distress, bankruptcy and reorganization. In R. Z. Jarrow, Handbook of Operation Research and Management Science, vol 9 (pp. 921-961). Elsevier.

Shleifer, A., Vishny, R. (1992). Liquidation values and debt capacity: a market equilibrium approach. Journal of Finance 47, 1343-1366.

Spilimbergo, et.al. (2008). Fiscal Policy for the Crisis, MF Staff Position Note SPN/08/. Washington D.C.: IMF.

Stiglitz, J. (2009, April 1). Obama's Ersatz Capitalism . Retrieved October 10, 2017, from The New York Times: http:/ /www.nytimes.com/2009/04/01/opinion/01stiglitz.htmlWang B., Wang X. (n.d.). The Researches on the Theory of Assets Securitization and Feasibility in Polyclinic. Retrieved from http:/ / www.seiofbluemountain.com/upload/product/200911/2008qyjihy05a16.pdf

Wang, W. (2016, April 5). Bank need to avoid risks in debt-for-equity-swap. Retrieved October 7, 2017, from Global Times: http://www.globaltimes.cn/content/977145.shtml

Wildau, G. \& Weinland, D. (2016, April 23). China debt load reaches record high as risk to economy 
Gadjah Mada International Journal of Business - September-December, Vol. 22, No. 3, 2020

mounts: US-style credit crunch or Japan-style grinding malaise seen as increasingly likely. Financial Times. Retrieved June 9, 2018, from https://www.ft.com/content/acd3f2fc-084a-11e6-876db823056b209b

WuH.Y., Tzenga G.H, Chen Y.H. (2011). A fuzzy MCDM approach for evaluating banking performance based on balanced scorecard. Taiwan.

Xinhuanet. (2016, October 28). China to keep proactive fiscal policy, prudent monetary policy. Retrieved June 9, 2018, from http://www.xinhuanet.com/english/2016-10/28/c_135788494.htm 2016-10-28

YalcinSecme N., Bayrakdaroghu A., CengizKahramanb. (2007). Fuzzy performance evaluatioin in Turkish Banking Sector using Analytic Hierachy Process and TOPSIS. Expert Systems with Application, 36, 11699-11709.

Zhang, S. \& Miller, M. (2016, May 12). China's non-performing loans hit 11-year high - regulator. Reuters. Retrieved June 9, 2018, from https://www.reuters.com/article/china-economy-loans/update-1-chinas-non-performing-loans-hit-11-year-high-regulator-idUSL3N18935N 


\section{Appendices}

\section{Appendix 1: AHP process}

In order to calculate the weight of each alternative, this research used the analytic hierarchy process (AHP).

There are:

- $\quad$ m alternatives to assess. Call $A_{i}$ with $i=1,2,3, \ldots, m$

- $\quad$ n criteria to asses. Call $C_{j}$ with $j=1,2,3, \ldots, n$

- $\quad$ k groups of decision-makers. Call $D_{r}$ with $r=1,2,3, \ldots, k$

So, we have:

- $\quad \widetilde{X_{j l}^{r}}$ is an assessment value of decision-maker $D_{r}$ about criteria $C_{j}$ for alternative $A_{i}$

- $\quad W_{j}^{r}$ is the weight of criteria $C_{j}$ evaluated by decision - maker $D_{r}$

(i) Step 1: Calculate the average weight of each criterion

$$
\widetilde{W_{J}}=\frac{1}{k} x\left(W_{j}^{1}+W_{j}^{2}+\cdots+W_{j}^{k}\right)
$$

Calculate the average value of each alternative

$$
\widetilde{X_{\jmath l}}=\frac{1}{k} x\left(\widetilde{X_{\jmath l}^{1}}+\widetilde{X_{\jmath l}^{2}}+\cdots+\widetilde{X_{\jmath l}^{k}}\right)
$$

We have the matrix related to decision making as follows:

$$
\begin{aligned}
& \begin{array}{lllllll}
C_{1} & C_{2} & \ldots \ldots & C_{j} & \ldots \ldots & C_{n}
\end{array}
\end{aligned}
$$

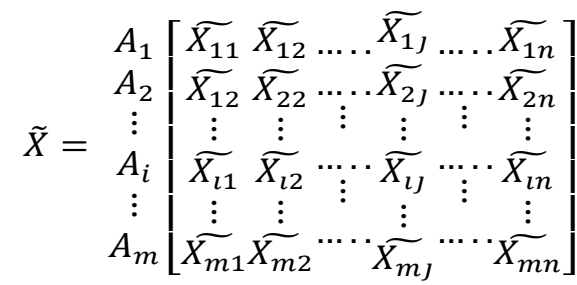

We have the matrix related to criteria weight as follows:

$$
\widetilde{W}=\left[\begin{array}{llll}
\widetilde{w_{1}} \widetilde{w_{2}} & \ldots . & \widetilde{w_{J}} & \ldots . \\
\widetilde{w_{n}}
\end{array}\right]
$$

(ii) Step 2: Establish the pairwise comparison matrix of criteria, the relative reciprocal matrix of criteria and calculate the EBQ ranking vector for the criteria.

We have $t$ the pairwise comparison matrix of criteria as follows:

Where:

$$
\begin{aligned}
& \begin{array}{lllllll}
C_{1} & C_{2} & \ldots \ldots & C_{j} & \ldots \ldots & C_{n}
\end{array}
\end{aligned}
$$

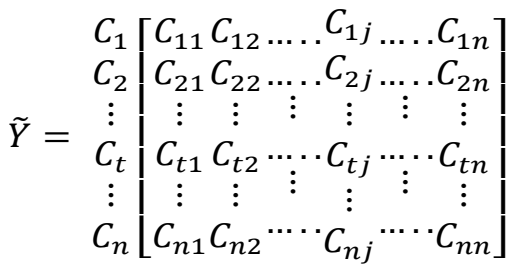

$$
C_{t j}=\frac{\widetilde{w_{t}}}{\widetilde{w_{J}}} \text { with } t, j=1,2, \ldots, n
$$

We have $\mathrm{t}$ relative reciprocal matrix of criteria as follows:

$$
\begin{array}{lllllll}
C_{1} & C_{2} & \ldots & C_{j} & \ldots & C_{n}
\end{array}
$$


Where:

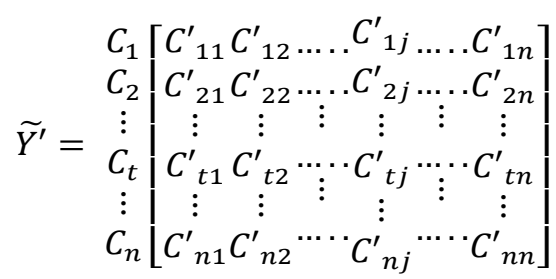

$$
C_{t j}^{\prime}=\frac{C_{t j}}{\sum C_{t j}}
$$

And we calculate the derived priorities (weights) for the criteria as follows:

$$
E B Q_{j}=\frac{\sum C^{\prime} t j}{n}
$$

with $\mathrm{t}$ is $1,2, \ldots, \mathrm{n}$ accordingly and $\mathrm{j}$ is from 1 to $\mathrm{n}$ for each value of $\mathrm{t}$

(iii) Step 3: Check the consistency of judgments

The research calculates a consistency ratio (CR) comparing the consistency index (CI) of the matrix in question versus the consistency index of a random-like matrix (RI).

$$
C R=\frac{C I}{R I}
$$

$\mathrm{CI}$ is calculated as follows:

$$
\begin{aligned}
& \text { Weighted sum }\left[C_{j}\right]=\sum C_{t j} x E B Q_{j} \\
& \text { Consistensive vector }\left[D_{j}\right]=\frac{\left[C_{j}\right]}{\left[E B Q_{j}\right]} \\
& \alpha=\frac{\text { Sum }[D]}{k} \\
& C I=\frac{\alpha-k}{k-1}
\end{aligned}
$$

According to Saaty (2012), the RI value for matrices of size 4 is 0.9 and simultaneously, consistency ratio (CR) of 0.10 or less is acceptable to continue the AHP analysis (Saaty, 2012). In case RI or CR does not satisfy the above conditions, it is necessary to revise the judgments to locate the cause of the inconsistency and correct it.

(iv) Step 4: Establish the pairwise comparison matrix of alternatives for each criterion, the relative reciprocal matrix of alternatives, with respect to each criterion by using the numeric scale and calculate the EBQ ranking vector of alternatives for each criterion $\left(E B Q_{j i}\right)$. This step is executed in a similar manner to the second step.

(v) Step 5: Calculate the value of each alternative; the higher the value is the better it is.

$$
\begin{aligned}
& V_{i}=\sum E B Q_{j} x E B Q_{j i} \\
& \text { With } \mathrm{i}=1,2, \ldots \mathrm{m} \text { and } \mathrm{j}=1,2, \ldots \mathrm{n}
\end{aligned}
$$

\section{Appendix 2: Fuzzy TOPSIS process}

Fuzzy scale is presented as follows.

\begin{tabular}{ll}
\hline Linguistic value & Triangular FN $\left(\widetilde{\boldsymbol{a}}_{\boldsymbol{i} \boldsymbol{j}}\right)$ \\
\hline Very low (bad) & $(0 ; 0.1 ; 0.3)$ \\
Low (bad) & $(0.2 ; 0.4 ; 0.5)$ \\
High (good) & $(0.3 ; 0.5 ; 0.7)$ \\
Very high (good) & $(0.7 ; 0.9 ; 1.0)$ \\
\hline
\end{tabular}


(i) Step 1: Calculate fuzzy rating of the decision maker $D_{r}$ about alternative $A_{i}$ about criterion $C_{j}$

There are T questions for criterion $C_{j}$. So, we have:

- $\quad \widetilde{X_{l J}^{r} t}$ is the fuzzy rating of the decision maker $D_{r}$ about alternative $A_{i}$ about question $\mathrm{t}$ in criterion $C_{j}$

$$
\widetilde{X_{l j}^{r}}=\left(a_{i j}^{r t}, b_{i j}^{r t}, c_{i j}^{r t}\right)
$$

- $\quad \widetilde{X_{l j}^{r}}$ is the fuzzy rating of the decision maker $D_{r}$ about alternative $A_{i}$ about criterion $C_{j}$

$$
\widetilde{X_{l j}^{r}}=\left(a_{i j}^{r}, b_{i j}^{r}, c_{i j}^{r}\right)
$$

$$
a_{i j}^{r}=\frac{1}{T} \sum_{t=1}^{T} a_{i j}^{r t} ; b_{i j}^{r}=\frac{1}{T} \sum_{t=1}^{T} b_{i j}^{r t} ; c_{i j}^{r}=\frac{1}{T} \sum_{t=1}^{T} c_{i j}^{r t}
$$

(ii) Step 2: Calculate the aggregated fuzzy ratings for alternatives. The aggregated fuzzy rating $\tilde{X}_{i j}=\left(a_{i j}, b_{i j}, c_{i j}\right)$ of alternative $A_{i}$ with criterion $C_{j}$ is calculated by the formulas:

$$
a_{i j}=\min \left(a_{i j}^{r}\right) ; b_{i j}=\frac{1}{k} \sum_{r=1}^{k} b_{i j}^{r} ; c_{i j}=\max \left(c_{i j}^{r}\right)
$$

(iii) Step 3: Compute the normalized fuzzy decision matrix $\overline{\bar{R}}=\left[\tilde{X}_{i j}\right]$

$$
\tilde{X}_{i j}=\left(\frac{a_{i j}}{c_{j}^{*}}, \frac{b_{i j}}{c_{j}^{*}}, \frac{c_{i j}}{c_{j}^{*}}\right) \text { and } c_{j}^{*}=\max \left(c_{i j}\right)
$$

So we have the normalized fuzzy decision matrix as follows:

$$
\begin{aligned}
& \begin{array}{lllll}
\mathbf{C}_{1} & \mathbf{C}_{2} & \ldots & \mathbf{C}_{n-1} & \mathbf{C}_{n}
\end{array} \\
& \begin{array}{cc||ccccc||} 
& \mathbf{A}_{1} & \tilde{X}_{11} & \tilde{X}_{12} & \ldots & \tilde{X}_{1 n-1} & \tilde{X}_{1 n} \\
& \mathbf{A}_{2} & \tilde{X}_{21} & \tilde{X}_{22} & \ldots & \tilde{X}_{2 n-1} & \tilde{X}_{2 n} \\
& & & \ldots & \ldots & \ldots & \ldots \\
& \mathbf{A}_{\mathbf{m}-\mathbf{1}} & \tilde{X}_{m-11} & \tilde{X}_{m-12} & \cdots & \tilde{X}_{m-1 n-1} & \tilde{X}_{m-1 n} \\
& \mathbf{A}_{\mathbf{m}} & \tilde{X}_{m 1} & \tilde{X}_{m 2} & \ldots & \tilde{X}_{m n-1} & \tilde{X}_{m n}
\end{array}
\end{aligned}
$$

(iv) Step 4: Compute the weighted normalized fuzzy decision matrix

The research supposed that the criteria had the same importance. This means that the aggregated fuzzy weight $\widetilde{W}_{j}$ for each criterion $C_{j}$ is computed as follows:

$$
\begin{gathered}
W_{j}=(0.7,0.9,1.0) \\
\tilde{V}=\left(\tilde{v}_{i j}\right), \text { where } \tilde{v}_{i j}=\tilde{X}_{i j} x w_{j}
\end{gathered}
$$

So we have the weighted normalized fuzzy decision matrix as follows:

$$
\begin{aligned}
& \begin{array}{lllll}
\mathbf{C}_{1} & \mathbf{C}_{2} & \cdots & \mathbf{C}_{\mathbf{n}-1} & \mathbf{C}_{\mathbf{n}}
\end{array}
\end{aligned}
$$

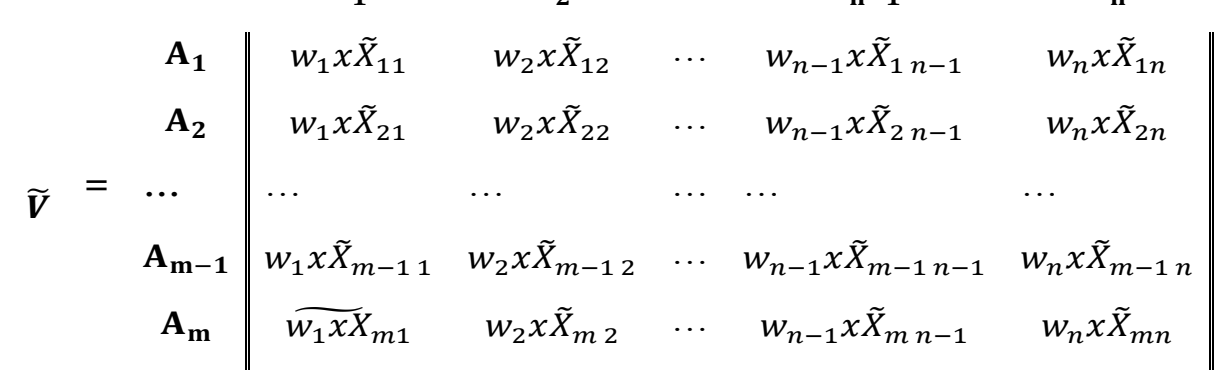


(v) Step 5: Compute the fuzzy positive ideal solution (FPIS $-A^{+}$) and fuzzy negative ideal solution (FNIS - $A^{-}$)

$$
\begin{aligned}
& A^{+}=\left(\tilde{v}_{1}^{+}, \tilde{v}_{2}^{+}, \ldots, \tilde{v}_{n}^{+}\right) \text {where } \tilde{v}_{j}^{+}=\max \left(v_{i j 3}\right) \\
& A^{-}=\left(\tilde{v}_{1}^{-}, \tilde{v}_{2}^{-}, \ldots, \tilde{v}_{n}^{-}\right) \text {where } \tilde{v}_{j}^{-}=\min \left(v_{i j 2}\right)
\end{aligned}
$$

(vi) Step 6: Calculate the distance from each alternative $A_{i}$ to the FPIS $\left(d_{i}^{+}\right)$and to the FNIS $\left(d_{i}^{-}\right)$

$$
\begin{aligned}
& d_{i}{ }^{+}=\sum_{j=1}^{n} d\left(\tilde{v}_{i j}, \tilde{v}_{j}^{+}\right) \\
& d_{i}{ }^{-}=\sum_{j=1}^{n} d\left(\tilde{v}_{i j}, \tilde{v}_{j}^{-}\right)
\end{aligned}
$$

According to Bojadziev et al (1995) the distance between two triangular fuzzy numbers $\widetilde{\mathrm{X}}=$ $\left(\mathrm{a}_{1}, \mathrm{~b}_{1}, \mathrm{c}_{1}\right)$ and $\tilde{\mathrm{y}}=\left(\mathrm{a}_{2}, \mathrm{~b}_{2}, \mathrm{c}_{2}\right)$ is calculated as follows:

$$
d(\tilde{x}, \tilde{y})=\sqrt{\frac{1}{3}\left[\left(a_{1}-a_{2}\right)^{2}+\left(b_{1}-b_{2}\right)^{2}+\left(c_{1}-c_{2}\right)^{2}\right]}
$$

(vii) Step 7: Calculate the closeness coefficient $C C_{i}$ for each alternative $A_{i}$.

$$
C C_{i}=\frac{d_{i}^{-}}{d_{i}^{-}+d_{i}^{*}}
$$

\begin{tabular}{|c|c|c|c|c|c|}
\hline & & $\begin{array}{c}\text { Legal } \\
\text { Framework } \\
\text { (C1) }\end{array}$ & $\begin{array}{l}\text { Intermediary } \\
\text { Parties } \\
\text { (C2) }\end{array}$ & $\begin{array}{c}\text { Directly } \\
\text { Concerned } \\
\text { Parties } \\
\text { (C3) }\end{array}$ & $\begin{array}{c}\text { Market } \\
\text { Conditions } \\
\text { (C4) }\end{array}$ \\
\hline A1 & $\begin{array}{l}\text { Non-Performing Loans } \\
\text { Write-Offs by Loan Loss } \\
\text { Reserves }\end{array}$ & 3.43 & 2.76 & 3.45 & 3.50 \\
\hline A2 & Liquidation of Collateral & 2.85 & 2.26 & 3.45 & 2.82 \\
\hline A3 & Debt - Equity Swap & 2.43 & 2.17 & 2.33 & 2.17 \\
\hline A4 & Securitization & 1.63 & 1.91 & 2.04 & 1.63 \\
\hline
\end{tabular}

(viii) Step 8: Rank the resolution of NPLs in descending order. The highest closeness coefficient represents the best solution.

Appendix 3: Matrix related to decision making in AHP approach

Appendix 4: Pairwise comparison matrix with intensity judgments in AHP approach

\begin{tabular}{llcccc}
\hline & $\begin{array}{c}\text { Legal } \\
\text { Framework }\end{array}$ & $\begin{array}{c}\text { Intermediary } \\
\text { Parties }\end{array}$ & $\begin{array}{c}\text { Directly } \\
\text { Concerned } \\
\text { Parties }\end{array}$ & $\begin{array}{c}\text { Market } \\
\text { Conditions }\end{array}$ \\
& $(\mathrm{C} 1)$ & $(\mathrm{C} 2)$ & $(\mathrm{C} 3)$ & $(\mathrm{C} 4)$ \\
\hline C1 & Legal Framework & 1.00 & 1.19 & 1.02 & 1.07 \\
C2 & Intermediary Parties & 0.84 & 1.00 & 0.86 & 0.90 \\
C3 & Directly Concerned Parties & 0.98 & 1.17 & 1.00 & 1.05 \\
C4 & Market Conditions & 0.94 & 0.12 & 0.95 & 1.00 \\
\hline
\end{tabular}


Appendix 5: EBQ ranking vector for criteria in AHP approach

\begin{tabular}{llc}
\hline & & EBQ Ranking Vector \\
\hline C1 & Legal Framework & 0.29 \\
C2 & Intermediary Parties & 0.24 \\
C3 & Directly Concerned Parties & 0.28 \\
C4 & Market Conditions & 0.20 \\
\hline & & Source: Authors
\end{tabular}

Appendix 6: Calculation of CR in AHP approach

\begin{tabular}{|c|c|c|c|}
\hline & Weighted sum & Priority & \\
\hline $1.06 /$ & & 0.29 & 3.73 \\
\hline $0.89 /$ & & 0.24 & 3.73 \\
\hline $1.04 /$ & & 0.28 & 3.73 \\
\hline \multirow[t]{6}{*}{$0.76 /$} & & 0.20 & 3.88 \\
\hline & Total & & 15.08 \\
\hline & Divide total by & Lambda max & 3.77 \\
\hline & & $\mathrm{CI}$ & $(0.08)$ \\
\hline & & RI & 0.90 \\
\hline & & CR & $(0.09)$ \\
\hline
\end{tabular}

Appendix 7: Fuzzy Positive Ideal Solution (FPIS - $A^{+}$) and Fuzzy Negative Ideal Solution

\begin{tabular}{ccccc}
\multicolumn{5}{c}{$\left(\mathbf{F N I S}-\boldsymbol{A}^{-}\right)$} \\
\hline A+ & 1.00 & 0.88 & 1.00 & 1.00 \\
A- & 0.32 & 0.30 & 0.33 & 0.24 \\
\hline \multicolumn{4}{c}{ Source: Authors }
\end{tabular}

Appendix 8: The distance from each alternative $A_{i}$ to the FPIS $\left(d_{i}^{+}\right)$and to the FNIS $\left(d_{i}^{-}\right)$

\begin{tabular}{ccccc}
\hline Alternatives & $\mathbf{A 1}$ & $\mathbf{A 2}$ & $\mathbf{A 3}$ & $\mathbf{A 4}$ \\
\hline $\mathbf{d}+$ & 1.9850 & 2.2596 & 2.4813 & 2.7900 \\
$\mathbf{d}-$ & 1.7227 & 1.3066 & 1.1127 & 1.0694 \\
\hline \multicolumn{4}{r}{} & \multicolumn{3}{c}{ Source: Authors }
\end{tabular}

